\title{
Perilaku Perawatan Luka Perinium, Pola Hidup Sehat dan Kondisi Kesehatan Ibu Post Partum Masa Pandemi Covid-19
}

\author{
Islah Wahyuni \\ Email: islah_fattan@yahoo.co.id \\ D-III Kebidanan Stikes Payung Negeri Pekanbaru, Indonesia \\ Jalan Tamtama No.6 Kelurahan Labuh Baru Kecamatan Payung Sekaki Pekanbaru Riau, Indonesia \\ Telp. (0761) 885214
}

\begin{abstract}
Abstrak
Masa pandemic covid-19 perlunya upaya penanganan pencegahan infeksi kepada ibu dan bayi serta keluarga yang lain. Infeksi pada ibu dalam kehamilan menyumbang $11 \%$ penyebab morbiditas ibu maternal, masa yang paling rentan untuk terjadinya infeksi adalah pada masa nifas atau masa setelah persalinan. Faktor yang memudahkan terjadinya infeksi nifas adalah luka jalan lahir.Luka ini dapat menjadi jalan masuk mikroorganisme.Pola hidup sehat juga merupakan factor mempengaruhi penyembuhan luka perineum pada ibu nifas, didapatkan hubungan antara pengetahuan, gizi, olahraga dan personal hygiene ibu nifas. Luka perineum membutuhkan waktu untuk sembuh selama 2-3 minggu dan selama proses penyembuhan tersebut dibutuhkan perawatan luka perineum yang baik agar terhindar dari infeksi. Tujuan penelitian mengidentifikasiPerilaku Perawatan Luka Perinium, Pola Hidup Sehat dan kondisi kesehatan ibu post partum Masa Pandemi Covid-19 di BPM Islah Wahyuni. Sampel penelitian 30 responden adalah ibu post partum pada 10 Maret - 25 Juni 2020. Hasil penelitian didapatkan Perilaku Perawatan Luka Perinium baik 27 responden (90\%), Lama Penyembuhan $<3$ minggu 20 responden (80\%), Kejadian Infeksi Perinium 0\%, kondisi fisik sehat (96,7\%). Diharapkan agar ibu post partum mempertahankan praktek perawatan luka perineum dan kewaspadaan dalammenjaga kesehatan serta mencegah penularan infeksi post partum dalam masa pandemic covid-19.
\end{abstract}

Kata Kunci: luka perinium; pola hidup sehat; pandemi covid-19; post partum.

\begin{abstract}
The pandemic covid-19 needs to be an effort to handle infection prevention for mothers and infants. Infection in pregnancy accounts for $11 \%$ of the causes maternal morbidity, the most vulnerable period for infection is in the puerperium or after delivery. One of the factors that facilitate infection is wound the birth canal. It can be a pathway for microorganisms. A healthy lifestyle is also a factor influencing the healing of perineal wounds. There is a relationship between of knowledge, nutrition, exercise and personal hygiene. Perineal injury requires time to heal for 23 weeks and it takes good care of the perineal wound to avoid infection. The purpose of the study was to identify the behavior of perineal Wound Care, Healthy Lifestyle and post partum maternal health conditions during the Covid-19 Pandemic at BPM Islah Wahyuni. The sample of 30 respondents were post partum on March 10 to June 25, 2020. The results obtained from the Behavioral Care of Perineal Injury both 27 respondents 90\%, Healing Time $<3$ weeks 20 respondents $(80 \%)$, PerinealInfection $0 \%$, conditions physically healthy $(96.7 \%)$. Post partum mothers should maintain perineal wound care, promote health and preventing transmission of post partum infection during this pandemic covid-19.
\end{abstract}

Keywords: perinium injury; healthy lifestyle; covid-19 pandemic; post partum. 
Jurnal Kebidanan Harapan Ibu Pekalongan

\section{Pendahuluan}

Angka Kematian Ibu (AKI) di Indonesia disebabkan oleh $75 \%$ perdarahan pasca lahir, infeksi post partum dan hipertensi, partus lama, aborsi yang tidak aman. ${ }^{(1)}$ Infeksi Post Partum memberikan kontribusi kesakitan dan kematian pada ibu maternal hingga $11 \%$. $^{(2)}$ Ini menunjukkan infeksi postpartum pada ibu merupakan komplikasi yang dapat terjadi dari persalinan dan perlu upaya pencegahan terhadap resistensi antimikroba. ${ }^{(2)}$

Wabah pandemic Covid-19 yang berkembang saat ini sudah ditetapkan pemerintah Bencana Non Alam sesuai dengan Keputusan Presiden Republik Indonesia Nomor 12 Tahun 2020. (3) Penyebaran Covid-19 sudah menyebar dari waktu kewaktu sehingga telah merugikan kesehatan masyarakat di Indonesi $^{(4)}$. Hal ini tentunya sangat berpengaruh terhadap kesehatan ibu dan anak, yang mana dalam kondisi normal masih meningkat jumlah kesakitan dan kematian ibu dan anak masih tinggi ${ }^{(5)}$.Saat wabah Covid-19 pelayanan kesehatan ibu dan anak dibatasi karena dikhawatirkan penularannya yang cepat kepada ibu dan anak ${ }^{(3)}$. Begitu juga dengan pelayanan kehamilan, persalinan, nifas dan bayi baru lahir mesti mendapatkan perhatian khusus dari petugas kesehatan. Ada beberapa hal yang mesti diperhatikan ibu nifas dalam menjaga kesehatan ibu dan bayinya, kunjungan nifas tetap dilaksanakan 4 kali dengan membuat perjanjian dengan tenaga kesehatan kunjungan rumah atau hanya melalui media online. ${ }^{(3)}$

Peningkatan risiko infeksi mesti dicegah pada masa pandemic wabah Covid-19 ini, Ibu nifas beresiko terjadi infeksi pasca persalinan yang meningkat dengan luka perineum yang tidak terawat dengan baik, dimana jalan masuk bagi mikroorganisme penyebab infeksi dan jaringan nekrosis di sekitar perineum yang luka merupakan media yang paling subur bagi perkembangan mikroorganisme ${ }^{(6)}$ perilaku yang dianjurkan bagi ibu nifas adalah mencuci tangan, menjaga jarak dan memakai masker dengan menjaga kebersihan diri dan bayinya. ${ }^{(3)}$

Asuhan kebidanan pada masa nifas asuhan kebidanan difokuskan untuk upaya preventif. Resiko infeksi luka perineum ini dapat dicegah atau diminimalkan salah satunya yaitu dengan melakukan perawatan perineum yang benar ${ }^{(7)}$. Infeksi perineum akan berdampak kepada lamanya proses penyembuhan luka perineum dan memberikan efek buruk bagi kesehatan ibu dan bayi (2). Luka perineum akan sembuh dalam 2-3 minggu pasca melahirkan (7). Pentingnya peran tenaga kesehatan dan perilaku kesehatan yang tepat saat masa wabah covid ini akan membantu dalam meningkatkan kesehatan ibu dan anak dan mencegah kejadian infeksi pada mereka $^{(5)}$. Perilaku merupakan suatu kegiatan atau aktivitas organisme dalam berespon atau bereaksi terhadap ransangan atau stimulus dari luar dirinya yang dapat menjadi behavior atau habit pada dirinya ${ }^{(8)}$. Perilaku yang baik dalam perawatan luka perineum akan mempengaruhi proses penyembuhan luka perineum.

Agar tidak terjadi infeksi maka dapat dilakukan dengan melakukan perawatan luka perineum yang benar.Menjaga daerah perineum senantiasa bersih dan kering, jangan biarkan lembab. Mencuci 
Jurnal Kebidanan Harapan Ibu Pekalongan

tangan sebelum dan sesudah mengganti pembalut atau menyentuh daerah kelamin. Bersihkan vagina dari arah depan ke belakang untuk mencegah kontaminasi bakteri dari anus. Keringkan daerah kemaluan dengan gerakan menepuk. Mengganti pembalut secara teratur 4-5 kali sehari. Hindari menyentuh bagian pembalut yang menempel ke kulit ${ }^{(6)}$. Pentingnya pola hidup sehat selama masa Nifas juga mendukung untuk proses penyembuhan luka dan menjaga kondisi ibu tetap sehat selama menjalani masa nifas.

Studi pendahuluan pada 3 ibu hamil dan 5 ibu post partum di BPM Islah Wahyuni tanggal 4-5 Maret 2020, diperoleh informasi bahwa pada masa pandemi ini banyak ibu hamil yang menolak melahirkan di rumah sakit atau di puskesmas, dengan alasan ketakutan dalam isolasi yang akan dilakukan dan prosedur tindakan yang mesti dilaluinya lebih banyak saat dirawat di rumah sakit.Saat ini bidan praktek swasta masih memberikan pelayanan pertolongan persalinan yang aman dengan mengikuti protocol APD tingkat 2. Dari 5 ibu post partum terdapat 3 orang memiliki luka perineum, mereka membersihkan genetalia dan mencuci luka perineum dengan air sabun, dan 2 orang tidak mengeringkan daerah genetalia setelah $\mathrm{BAB}$ dan $\mathrm{BAK}$, tidak ada tanda-tanda infeksi jalan lahir, lama penyembuhan 2-3 minggu, 3 orang diantaranya adanya gangguan pola istirahat dan mobilitas ibu dalam beraktivitas sehari-hari.

$\begin{array}{lr}\text { Berdasarkan } & \text { masalah } \\ \text { diatas, peneliti } & \text { melakukan } \\ \text { penelitian dengan judul "Perilaku } & \text { Perawatan Luka Perinium, Pola }\end{array}$

Hidup Sehat dan kondisi kesehatan Ibu Post Partum Dalam Masa Pandemi Covid-19" Di BPM Islah Wahyuni.

\section{Metode Penelitian}

Penelitian ini adalah Deskriptif Analitik dengan Desain crosssectional, yaitu penelitian yang bertujuan untuk melihat gambaran suatu objek dengan suatu keadaanlainnya secara objektif. Dalam penelitian ini menggambarkan Perilaku Perawatan Luka Perinium,Pola Hidup Sehat dan kondisi kesehatan Ibu Post Partum Dalam Masa Pandemi Covid-19 Di BPM Islah Wahyuni.

Populasi penelitian adalah ibu bersalin dari 2018-2019 sebanyak 105 orang, pengambilan sampel secara Purposive sampling, yaitu peneliti menentukan pengambilan sampel dengan cara menetapkan ciri-ciri khusus yang sesuai dengan tujuan penelitian sehingga diharapkan dapat menjawab permasalahan penelitian ${ }^{(9)}$. Sampel penelitian berjumlah 30 orang yang melahirkan dari bulan Maret sampai Juni 2020 yang memiliki luka perineum baik Primipara maupun Multipara.

Instrument

penelitian menggunakan kuesioner dan catatan partus pasien yang ada di klinik Bidan, dengan mengindentifikasi praktek perawatan perineum saat dirumah, lama penyembuhan, kejadian infeksi perineum dan pola hidup sehat ibu dalam masa Pandemi Covid-19. 
Jurnal Kebidanan Harapan Ibu Pekalongan

\section{Hasil dan Pembahasan}

\section{Hasil Penelitian}

a. Data Umum

Hasil penelitian terhadap karakteristik responden dalam penelitian ini dapat dilihat pada tabel sebagai berikut :

\section{Karakteristik Responden}

Tabel 1.1 Distribusi Frekuensi Karakteristik Responden di BPM Islah Wahyuni

\begin{tabular}{|c|c|c|c|c|}
\hline No & Perilaku & $\mathbf{N}$ & Jumlah & $\begin{array}{c}\text { Persentase } \\
(\%)\end{array}$ \\
\hline \multirow[t]{4}{*}{1} & Umur & 30 & & \\
\hline & $-\quad<20$ & & 0 & 0 \\
\hline & $-\quad 20-35$ & & 27 & 90 \\
\hline & $-\quad 35-45$ & & 3 & 10 \\
\hline \multirow[t]{4}{*}{2} & Pendidikan: & 30 & & \\
\hline & $\begin{array}{l}\text { - } \quad \text { Pendidikan } \\
\text { Dasar }\end{array}$ & & 12 & 40,0 \\
\hline & $\begin{array}{ll}\text { - } & \text { Pendidikan } \\
\text { Menengah }\end{array}$ & & 13 & 43,3 \\
\hline & $\begin{array}{l}\text { - } \quad \text { Pendidikan } \\
\text { Tinggi }\end{array}$ & & 5 & 16,7 \\
\hline \multirow[t]{3}{*}{3} & Pekerjaan: & 30 & & \\
\hline & - $\quad$ Bekerja & & 8 & 26,7 \\
\hline & $\begin{array}{ll}\text { - } & \text { Tidak } \\
& \text { Bekerja } \\
\end{array}$ & & 22 & 73,3 \\
\hline \multirow[t]{3}{*}{4} & $\begin{array}{l}\text { Lama Pasca } \\
\text { Bersalin }\end{array}$ & 30 & & \\
\hline & $\begin{array}{ll}-\quad \text { Minggu } \\
\text { Ke-3 }\end{array}$ & & 5 & 33,3 \\
\hline & $\begin{array}{ll}- & \text { Minggu } \\
\text { Ke-4 }\end{array}$ & & 20 & 66,7 \\
\hline 5 & Paritas & 30 & & \\
\hline & - $\quad$ Primipara & & 19 & 63,3 \\
\hline & - $\quad$ Multipara & & 11 & 36,7 \\
\hline
\end{tabular}

Berdasarkan Tabel 1.1 dapat diketahui bahwa, mayoritas responden di BPM Islah Wahyuni Tahun 2020 berdasarkan umur mayoritas 20-35 tahun sebanyak 27 orang (90\%), mayoritas berpendidikan Menengah sebanyak 13 orang $(43,3$ $\%$, mayoritas tidak bekerja sebanyak 22 orang $(73,3 \%)$, mayoritas pasca persalinan minggu ke-4 sebanyak 20 orang
$(66,7 \%)$, mayoritas paritas ibu Primipara sebanyak 19 orang $(63,3 \%)$.

2. Sumber Informasi

Tabel 1.2 Distribusi Frekuensi Responden Berdasarkan Sumber Informasi tentang perawatan luka perineum dan pola hidup sehat di BPM Islah Wahyuni

\begin{tabular}{llcc}
\hline No & Sumber Informasi & Frekuensi & \\
& & & $\mathbf{( \% )}$ \\
\hline 1 & Tenaga kesehatan & 20 & 66,7 \\
2 & Non tenaga kesehatan & 10 & 33,3 \\
\hline & Total & 30 & 100 \\
\hline
\end{tabular}

Berdasarkan Tabel 1.2 dapat diketahui bahwa, mayoritas responden di BPM Islah Wahyuni Tahun 2020 mendapatkan informasi dari tenaga kesehatan sebanyak 20 orang $(66,7 \%)$.

\section{b. Data Khusus}

Hasil penelitian Perilaku Perawatan Luka Perinium Dan Prilaku Kesehatan Ibu Post Partum Dalam Masa Pandemi Covid-19 responden dalam penelitian ini dapat dilihat pada tabel sebagai berikut :

\section{Perilaku Perawatan Luka Perinium}

\section{a. Perilaku perawatan luka perineum}

Tabel 1.3 Perilaku perawatan luka perineum Ibu Nifas di BPM Islah Wahyuni

\begin{tabular}{llcc}
\hline No & Uraian & Jumlah & $\begin{array}{c}\text { Persentase } \\
(\%)\end{array}$ \\
\hline 1 & Baik & 27 & 90 \\
2 & Tidak & 3 & 10 \\
& Baik & & \\
\hline & Jumlah & $\mathbf{3 0}$ & $\mathbf{1 0 0}$
\end{tabular}


Jurnal Kebidanan Harapan Ibu Pekalongan

Berdasarkan Tabel 1.3 diketahui bahwa mayoritas perilaku perawatan luka perinium responden di BPM Islah Wahyuni Tahun 2020 adalah Baik yaitu 27 orang $(90 \%)$.

\section{b. Pengetahuan dan sikap ibu dalam perawatan luka perineum}

Tabel 1.4 Pengetahuan dan sikap ibu dalam perawatan luka perineum Ibu Nifasdi BPM Islah Wahyuni

\begin{tabular}{|c|c|c|c|c|c|}
\hline No & Uraian & & $\mathbf{N}$ & Jumlah & $\begin{array}{c}\text { Persentase } \\
(\%)\end{array}$ \\
\hline \multirow[t]{4}{*}{1} & Penget & uan & 30 & & \\
\hline & 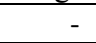 & Baik & & 4 & 13,3 \\
\hline & - & Cukup & & 17 & 56,7 \\
\hline & - & Kurang & & 9 & 30 \\
\hline \multirow[t]{3}{*}{2} & Sikap : & & 30 & & \\
\hline & - & Positif & & 26 & 86,7 \\
\hline & - & Negatif & & 4 & 13,3 \\
\hline
\end{tabular}

Berdasarkan

Tabel 1.4 diketahui bahwa mayoritas pengetahuan responden di BPM Islah Wahyuni Tahun 2020 berpengetahuan Cukup yaitu 17 orang $(56,7 \%)$, mayoritas sikap responden positif yaitu 26 orang $(86,7 \%)$.

\section{Pola Hidup Sehat Ibu Masa Nifas masa pandemi Covid 19}

Tabel 1.5 Pola Hidup sehat Ibu dalam masa Pandemi Covid 19 di BPM Islah Wahyuni

\begin{tabular}{|c|c|c|c|c|}
\hline No & $\begin{array}{c}\text { Pola Hidup sehat } \\
\text { Ibu }\end{array}$ & $\mathbf{N}$ & $\begin{array}{c}\text { Jumla } \\
\text { h }\end{array}$ & $\begin{array}{c}\text { Persentase } \\
(\%)\end{array}$ \\
\hline \multirow[t]{3}{*}{1} & Asupan Nutrisi : & 30 & & \\
\hline & - $\quad$ Baik & & 28 & 93,3 \\
\hline & - Kurang & & 2 & 6,7 \\
\hline \multirow[t]{3}{*}{2} & Personal Higiene: & 30 & & \\
\hline & - Baik & & 27 & 90 \\
\hline & - $\quad$ Kurang & & 3 & 10 \\
\hline \multirow[t]{3}{*}{3} & Olahraga Nifas: & 30 & & \\
\hline & - Dilakukan & & 20 & 66,7 \\
\hline & - $\quad$ Tidak dilakukan & & 10 & 33,3 \\
\hline \multirow[t]{3}{*}{4} & Istirahat & 30 & & \\
\hline & - Cukup & & 20 & 66,7 \\
\hline & - $\quad$ Kurang & & 10 & 33,3 \\
\hline \multirow[t]{10}{*}{5} & Pencegahan Covid: & & & \\
\hline & $\begin{array}{ll}\text { - } & \text { Social } \\
& \text { Distancing }\end{array}$ & 30 & & \\
\hline & - Baik & & 25 & 83,3 \\
\hline & - $\quad$ Kurang baik & & 5 & 16,7 \\
\hline & $\begin{array}{ll}\text { - } & \text { Mencuci } \\
& \text { Tangan } \\
\end{array}$ & 30 & & \\
\hline & - $\quad$ Baik & & 14 & 46,7 \\
\hline & - $\quad$ Kurang baik & & 16 & 53,3 \\
\hline & $\begin{array}{ll}\text { - } & \text { Penggunaan } \\
& \text { Masker }\end{array}$ & 30 & & \\
\hline & - Baik & & 13 & 43,3 \\
\hline & - Kurang baik & & 17 & 56,7 \\
\hline
\end{tabular}

Berdasarkan Tabel 1.5 diketahui bahwa mayoritas perilaku kesehatan responden dalam masa Pandemi Covid 19 di BPM Islah Wahyuni Tahun 2020, berdasarkan Asupan Nutrisi mayoritas Baik yaitu 28 orang $(93,3 \%)$, Personal Higiene Baik yaitu 27 orang (90\%). Olahraga Nifas dilakukan yaitu 20 orang (66,7\%), Istirahat Cukup yaitu 20 orang $(66,7 \%)$, 
Jurnal Kebidanan Harapan Ibu Pekalongan

Pencegahan penularan Covid-19 dengan Social Distancing Baik yaitu 25 orang $(83,3 \%)$, Mencuci Tangan Kurang Baik yaitu 16 orang $(53,3 \%)$, Penggunaan Masker Kurang Baik yaitu 17 orang $(56,7 \%)$.

\section{Kondisi kesehatan Ibu Post partum}

Tabel 1.6 Kondisi kesehatan Ibu Post partum dalam masa Pandemi Covid 19 di BPM Islah Wahyuni

\begin{tabular}{|c|c|c|c|c|}
\hline No & Kondisi Ibu & No & Jumlah & $\begin{array}{c}\text { Persentase } \\
(\%)\end{array}$ \\
\hline \multirow[t]{3}{*}{1} & $\begin{array}{l}\text { Lama penyembuhan } \\
\text { luka }\end{array}$ & 30 & & \\
\hline & $-\quad \geq 3$ minggu & & 2 & 6,7 \\
\hline & $-\quad<3$ minggu & & 28 & 93,3 \\
\hline \multirow[t]{3}{*}{2} & $\begin{array}{l}\text { Kejadian Infeksi } \\
\text { perinium }\end{array}$ & 30 & & \\
\hline & - $\quad$ Ada & & 0 & 0 \\
\hline & - $\quad$ Tidak ada & & 30 & 100 \\
\hline \multirow[t]{3}{*}{3} & $\begin{array}{l}\text { Kondisi fisik Ibu Post } \\
\text { partum }\end{array}$ & & & \\
\hline & - $\quad$ Sakit & & 1 & 3,3 \\
\hline & - $\quad$ Sehat & & 29 & 96,7 \\
\hline \multirow[t]{3}{*}{4.} & $\begin{array}{l}\text { Kondisi Psikis Post } \\
\text { partum }\end{array}$ & & & \\
\hline & $\begin{array}{ll}- & \text { Terganggu }\end{array}$ & & 4 & 13,3 \\
\hline & - Sehat & & 26 & 86,7 \\
\hline
\end{tabular}

Berdasarkan

Tabel 1.6 diketahui bahwa mayoritas kondisi kesehatan responden dalam masa Pandemi Covid 19 di BPM Islah Wahyuni Tahun 2020 berdasarkan lama penyembuhan luka perinium responden mayoritas $<3$ minggu yaitu 28 orang (93,3\%), dan tidak ada mengalami kejadian infeksi luka perinium yaitu 30 orang $(100 \%), \quad$ mayoritas kondisi ibu post partum adalah sehat yaitu 29 orang $(96,7 \%)$, mayoritas kondisi psikis ibu post partum adalah sehat yaitu 26 orang $(86,7 \%)$.

\section{a. Perilaku Perawatan}

\section{Luka Perinium}

Perawatan luka perineum yang benar menjadi sangat urgent dalam mencegah infeksi masa nifas pada ibu-ibu yang memiliki luka jalan lahir saat persalinannya, pengetahuan seputar kebersihan genetalia pasca bersalin harus dimiliki oleh ibu, luka menjadi bersih dan terawat apabila adanya kesadaran dan sikap peduli ibu terhadap kebersihan organ reproduksinya tersebut ${ }^{(10)}$

Pengetahuan

tentang luka pasca bersalin wajib diberikan bidan atau tenaga kesehatan lainnya setelah ibu berada dirumahnya, agar ibu dapat mengerti prosedur yang tepat dalam merawat luka perineum $^{(7)}$. Robekan perineum pada masa persalinan yang diakibatkan oleh keluarnya kepala dan tubuh bayi atau melalui tindakan episiotomi akan menimbulkan masalah dikemudian hari jika luka dibiarkan kotor dan tidak 
Jurnal Kebidanan Harapan Ibu Pekalongan

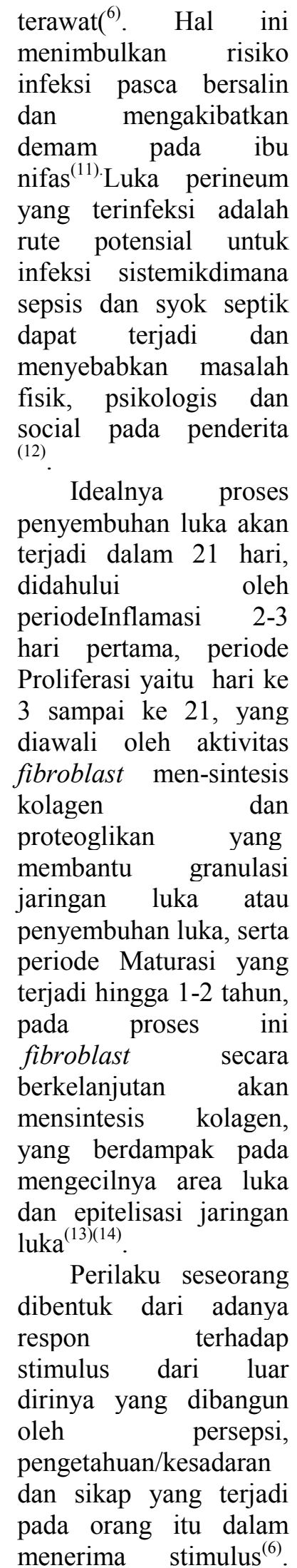

Perilaku yang benar dalam merawat luka perineum akan mempercepat penyembuhan luka $\left.{ }^{(15}\right)$.

Hasil penelitian

Nurrahmaton, Dewi

Sartika 2018, tentang

Hubungan Pengetahuan

Ibu Post Partum Tentang

Perawatan Luka

Perineum Dengan

Proses Penyembuhan

Luka Di Klinik Bersalin

Hj. Nirmala Sapni

Medan, yaituada

hubungan praktek

perawatan perineum

dengan lama

penyembuhan luka

perineum pada ibu nifas

dimana hasil chi-square

hitung $17,545>$ chi-

square tabel 5,991

dengan nilai value 0,000 $<0,05^{(7)}$

Faktor-faktor yang dapat mempengaruhi perilaku seseorang diantaranya adalah umur, pengalaman, paritas, pengetahuan, sikap, pendidikan dan lain-lain(8). Pada penelitian ini mayoritas responden penelitian berusia 20-35 tahun 27 orang (90\%), berdasarkan paritas mayoritas responden adalah primipara yaitu 19 orang $(63,3 \%)$.

Rupture perineum dapat terjadi secara spontan atau melalui episiotomy. Episiotomi merupakan tindakan memperlebar jalan lahir melalui insisi atau sayatan peada perineum, 
Jurnal Kebidanan Harapan Ibu Pekalongan

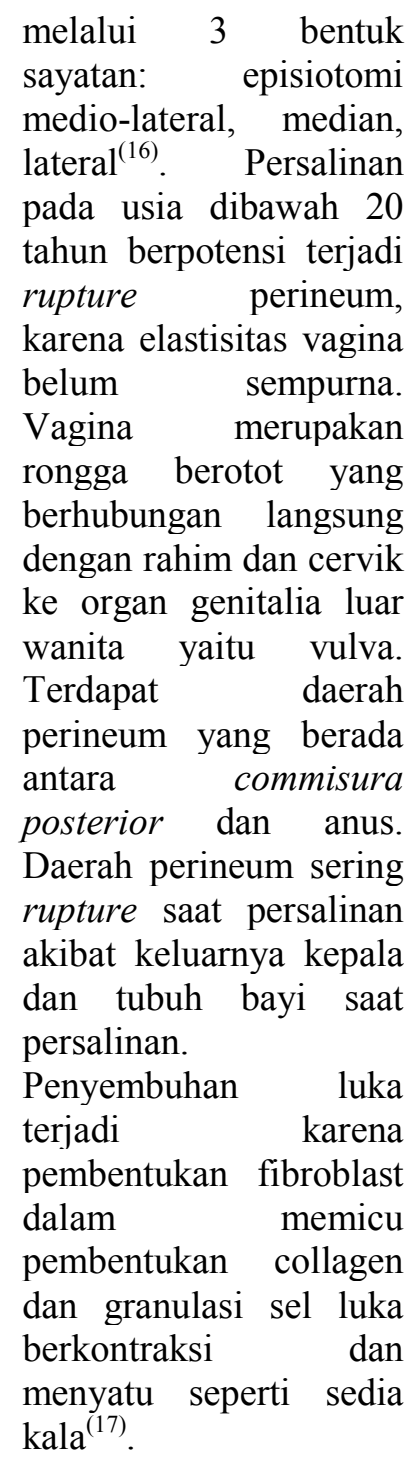

Kejadian rupture perineum lebih sering terjadi pada primipara, seperti hasil penelitian Prakirtia Primadona dan Dewi Susilowati 2015 tentang Penyembuhan Luka Perineum Fase Proliferasi Pada Ibu Nifas, diperoleh data berdasarkan umur responden terbanyak berusia antara 20-35 tahun yaitu sebanyak 27 responden (60\%), berdasarkan pendidikan responden terbanyak 26 responden $(57,78 \%)$
berpendidikan menengah, berdasarkan paritas responden paling banyak dengan karakteristik primipara yaitu sebanyak 23 responden $\quad(51,11 \%)$, dan berdasarkan status gizi responden paling banyak dengan karakteristik status gizi normal yaitu sebanyak 30 responden $(66,67 \%)$.

Umur yang matang akan mempengaruhi pola pikir seseorang dalam menjaga kebersihan vaginanya saat pasca melahirkan. Begitu juga Paritas, berkaitan dengan pengalaman sesorang dalam melakukan perawatan perineum, karena dipersalinan yang lalu pernah mengalami luka perineum sehingga lebih faham dalam merawat lukanya, ${ }^{(15)}$

Masa Pandemi
Covid 19ibu nifas diharapkan memiliki Pengetahuan perawatan luka perineum yang benar serta pemahaman tentang pencegahan infeksi dan penularan terhadap COVID-19 dalam hubungannya dengan kehamilan, bersalin dan nifas serta BBL yang sampai saat ini masih terbatas dan belum memiliki rekomendasi spesifik untuk penanganan kasusnya. Social distancing, pencucian 
Jurnal Kebidanan Harapan Ibu Pekalongan

tangan dan pemakaian APD adalah protocol umum yamng selalu disampaikan pemerintah agar semua orang termasuk ibu bersalian dan post partum terhindar dari infeksi covid 19. Untuk mewujudkan itu perlu upaya sinergi bidan, perawat dan tenaga kesehatan lainnya dan kesadaran ibu nifas dalam melakukan perawatan perinium ibu dan melakukan prosedur pencegahan Covid 19 sesuai protocol umum yang sudah ada ${ }^{(18) .}$

Diharapkan selama masa pandemi ini perempuan nifas dapat mengisolasi diri dirumah dan menghindari kontak fisik dengan orang lain selain keluarga, dan meminimalkan upaya untuk keluar dari rumah (19). Membatasi

kunjungan keluarga atau tamu yang berkunjung kerumah, jika terinfeksi demam, maka diharapkan segera akan memeriksakan diri ke fasilitas kesehatan ${ }^{(5)}$.

b. Pola hidup sehat dan kondisi kesehatan Ibu Nifas Masa Pandemi Covid-19

Perilaku yang diharapkan pada ibu nifas dalam menjaga kesehatannya pasca bersalin adalah healthy life style(5). Factor gizi, nutrisi, istirahat, olahraga nifas, dan pencegahan penularan covid 19 akan mempengaruhi kondisi kesehatan ibu saat nifas(20). Bagi ibu nifas yang ingin menyusui, tindakan pencegahan harus diambil untuk membatasi penyebaran virus covid 19 ke bayi dapat dilakukan dengan cara: Mencuci tangan saat memegang bayi, menggunakan pompa payudara atau botol jika ibu tidak memberikan ASI sepenuhnya, Ibu mesti menggunakan masker saat menyusui, dan mengurangi kontak fisik dengan orang luar atau tamu ${ }^{(5)}$.

Disamping itu gizi yang adekuat sangat membantu peningkatan imunitas tubuh melawan infeksi serta bermanfaat untuk proses penyembuhan luka, makanan yang kaya akan protein dan vitamin mineral sangat dianjurkan pada ibu post partum dengan luka perineum maupun tidak ada luka perineum ${ }^{(21)}$. Makanan yang kaya protein akan membentuk kollagen dan retikulin pada kulit sehingga fibroblast akan memicu proses penyembuhan luka atau granulasi jaringan akan lebih cepat terjadi (22), disamping itu Proses penyembuhan luka akan melibatkan aktivitas jaringan seluler : sel 
Jurnal Kebidanan Harapan Ibu Pekalongan

\begin{tabular}{|c|c|}
\hline \multirow{4}{*}{$\begin{array}{l}\text { darah, tissue types, } \\
\text { cytokines, dan growth } \\
\text { factors yang akan } \\
\text { menyebabkan }\end{array}$} & Wound Healing Among \\
\hline & Primiparous \\
\hline & diperoleh data bahwa \\
\hline & perbedaan \\
\hline peningkatan kebutuhan & signifikan ditemukan $(\mathrm{P}$ \\
\hline nutrisi pada luka. & antara \\
\hline Kondisi Kekurangan & kelompok, (perlakuan \& \\
\hline nutrisi & kontrol) pada 8 dan 14 \\
\hline menghalangi & hari setelah intervensi, \\
\hline penyembuhan luka, oleh & dimana ibu postpartum \\
\hline karena & kelompok \\
\hline penambahan Vitamin A & melakukan senam kegel \\
\hline diperlukan untuk & memiliki skor rata-rata \\
\hline pembentukan epitel dan & lebih sedikit mengalami \\
\hline tulang, seluler & intensitas nyeri \\
\hline diferensiasi, dan fungsi & dibandingkan \\
\hline kekebalan tubuh. & kelompok yang tidak \\
\hline Vitamin $\mathrm{C}$ diperlukan & melakukan $^{(16)}$ \\
\hline untuk pembentukan & Demikian \\
\hline kolagen, tepat fungsi & dengan hasil penelitian \\
\hline kekebalan tubuh, dan & Rasumawati, Marlinda, \\
\hline antioksidan & 2017 tentang Efektifitas \\
\hline jaringan.Vitamin & Latihan Senam Yoga \\
\hline adalah antioksidan & Terhadap \\
\hline utama yang larut dalam & Involusi Uterus Ibu \\
\hline lemak di kulit ${ }^{(23)}$ & Nifas di Praktek Mandiri \\
\hline Begitu juga dengan & Bidan di \\
\hline kegiatan senam atau & diperoleh data bahwa \\
\hline olahraga pada masa & ibu yang melakukan \\
\hline nifas.Olahraga yang & senam atau yoga akan \\
\hline rutin akan menjadikan & mengalami proses \\
\hline aliran darah menjadi & penurunan \\
\hline lancar sehingga tubuh & uterus 8,97 hari dan \\
\hline menjadi lebih bugar $^{(24)}$ & yang tidak melakukan \\
\hline membantu badan lebih & mengalami 13,70 hari, \\
\hline sehat dan mepercepat & dengan nilai $p$ value \\
\hline pemulihan organ & 0,0005 Sehingga \\
\hline reproduksi ${ }^{(25)}$ Olahraga & responden \\
\hline yang dianjurkan adalah & melakukan senam dan \\
\hline yoga, senam kegel dan & yoga akan mengalami \\
\hline senam nifas yang sudah & involusi uterus lebih \\
\hline bisa dilaksanakan sejak & cepat \\
\hline 6 jam post partum. & dibandingkan responden \\
\hline penelitian & yang \\
\hline Rania Eid Farrag, Abeer & melakukannya ${ }^{(26)}$. \\
\hline Saad Eswi, Haitham & penelitian \\
\hline Badran, 2016 tentang & Dalila, S, 2015 tentang \\
\hline Effect Of Postnatal & Pengaruh Senam Nifas \\
\hline Kegel Exercises on & Penguatan \\
\hline Episiotomy Pain and & Otot Perut Post Partum \\
\hline
\end{tabular}


Jurnal Kebidanan Harapan Ibu Pekalongan

terhadap 13 responden post partum diperoleh data bahwa ada pengaruh senam nifas terhadap penguatan otot perut dengan nilai $\mathrm{p}=0,005<=0,05^{(27)}$

BPM Islah wahyuni sudah menerapkan Senam Kegel dan Senam Nifas serta Yoga pada masa post Partum, dimulai sejak 6 jam pasca bersalin saat ibu masih di klinik, sampai 4 hari post partum saat kunjungan Nifas (KF) homecare, selanjutnya semua diserahkan kepada ibu Nifas untuk melakukannya sendiri dirumah. Namun pada data penelitian masih terdapat 10 orang ibu nifas $(66,7 \%)$ yang belum patuh melakukannya saat dirumah, dimana 6 diantaranya adalah ibu-ibu yang primipara, mereka merasa masih takut bergerak dan merasa nyeri pada luka periniumnya, sehingga banyak dari mereka yang mengabaikan latihan senam yang dianjurkan.

Disamping itu istirahat yang cukup juga akan membantu kenyamanan dan kesehatan ibu masa nifas, saat tidur hormone serotonin akan membuat seseorang menjadi relaks dan bugar saat bangun. Kecukupan istirahat pada ibu nifas dipengaruhi oleh beberapa hal seperti: tingkat stress, makanan, aktivitas fisik, perubahan hormone estrogen dan progesterone, dukungan keluarga, kesehatan bayi, dan lain-lain ${ }^{(28)}$

Kebutuhan istirahat ibu nifas pada minggu pertama kehidupan bayi sangat berkurang, karena proses adaptasi ibu dalam menyesuaikan kebutuhan pemberian ASI pada bayinya, seringnya ibu mengeluhkan kurang istirahat dan tidur dimalam hari akibat bayi mereka terbangun dan rewel akibat jumlah ASI yang belum memadai $^{(29),}$ seiring jumlah ASI semakin meningkat dan asupan nutrisi ibu sudah mencukupi sehingga bayi bisa kenyang dan tidak terlalu rewel dimalam hari, sehingga ibu bisa memenuhi kebutuhan istirahatnya jauh lebih baik dari minggu-minggu sebelumnya ${ }^{(28)}$. Proses menyusui juga memberikan tantangan tersendiri bagi ibu yang baru melahirkan sehingga kualitas tidur ibupun tidak baik, disamping itu tidak banyak penelitian yang membahas tentang kualitas tidur ibu selama masa post partum ini ${ }^{(29)}$

Penelitian Creti, et.all, 2017, tentang Sleep in the Postpartum: Characteristics of First-Time, Healthy Mothers menyatakan bahwa $50 \%$ respondennya saat $<18$ minggu pasca melahirkan masih memiliki tingkat mengantuk yang sangat tinggi di siang hari, akibat malam kurang tidur $^{(29)}$.

Kelelahan yang dialami ibu dalam merawat bayi apabila tidak disertai dengan dukungan keluarga dan suami akan membuat ibu mudah sakit dan stress, karena masa ini ibu memerlukan perhatian dan tingkat ketergantungan (dependen) yang sangat tinggi pada suami dan keluarga, efek 
Jurnal Kebidanan Harapan Ibu Pekalongan

ketidaknyamanan awal yang dapat dirasakan adalah ibu bisa mengalami keluhan nyeri kepala, kram perut, pusing, nafsu makan berkurang, letih dan tidak bersemangat, demam meriang, dan perasaan tidak nyaman diperut yang diakibatkan pola hidup yang kurang sehat dalam menjalani perubahan perannya menjadi seorang ibu pasca bersalin, namun demikikian perubahan pola istirahat ayah juga mesti menjadi perhatian agar tidak menjadi masalah stress antara suami istri dalam hal pengasuhan bayi mereka ${ }^{(28)}$. Menurut hemat peneliti, hal lain yang mesti kita cermati sebagai bidan, perawat dan tenaga kesehatan dalam memfasilitasi kesehatan ibu dan keluarga pada masa nifas adalah perubahan status ekonomi yang dialami keluarga selama masa Covid19 ini, dimana lockdown mempengaruhi pemasukan ekonomi kepala keluarga, ada kepala keluarga yang tidak bekerja sama sekali, bekerja lepas harian sebagai buruh atau tukang, jualan dipasar dan lain-lain.Adanya penambahan pengeluaran keluarga akibat kedatangan anggota keluarga baru yaitu bayi baru lahir, penambahan pembelian kuota internet bagi anak yang sedang sekolah dan kuliah daring online, sehingga hal ini akan mempengaruhi tingkat stres dan pikiran ibu nifas yang tentunya juga akan mempengaruhi kondisi kesehatannya selama masa post partum ini.

Dari data dapat dilihat bahwasanya ada 4 orang ibu yang mengalami masalah gangguan psikis terkait dengan perubahan ekonomi dalam keluarga yaitu 4 orang $(13,3 \%)$ yang mengaku adanya beban pikiran, dan merasa berat dengan kondisi ekonomi keluarga pada masa covid-19 ini, manifestasi yang mereka perlihatkan adalah emosi agak sulit terkontrol, lebih sensitive, kadang-kadang cemas untuk biaya makan, namun sejauh pemantauan penulis mereka masih tetap bisa bersabar dan beraktivitas seperti biasanya dan masih dapat menyusui bayinya dengan baik, sehingga secara fisik mayoritas ibu nifas masih tetap dalam keadaan sehat yaitu 29 orang $(96,7 \%)$, dimana Keadaan Umumnya baik, Tanda-tanda Vital Normal, tidak mengalami sakit dan infeksi saat pasca melahirkan, luka perineum kering dan tidak meradang.

Perantenaga kesehatan sangat penting dalam membantu menciptakan derajat kesehatan ibu post partum dalam masa Pandemi Covid-19 ini, memberikan edukasi dan informasi tentang seputar cara menjaga kesehatan, dan perlunya kunjungan ulang nifas (KF 1- KF 4) selama 6 minggu post partum wajib diterapkan dengan baik, dapat dilakukan dengan langsung mengunjungi dan follow up via telepon juga sangat disarankan pada masa pandemic Covid 19 ini $^{(3)(5)}$.

\section{Kesimpulan}

Perilaku Perawatan Luka Perinium, Pola Hidup Sehat dan kondisi kesehatan Ibu Post Partum Dalam Masa Pandemi Covid-19 
Jurnal Kebidanan Harapan Ibu Pekalongan

pada 30 responden penelitian menunjukkan hasil yang baik, dimana mayoritas responden memperlihatkan perilaku yang benar dan mematuhi saran bidan dalam merawat dirinya saat sudah berada dirumah, sehingga ini dibuktikan dengan kondisi temuan pola hidup yang sehat sudah terlaksana dengan baik, serta efeknya tidak ada responden yang memiliki kondisi sakit pasca melahirkan dan tidak ada yang mengalami infeksi luka jalan lahir postpartum dan rata-rata penyembuhan luka perineum juga cepat $(<3$ minggu), untuk itu sangat dibutuhkan peran aktif Bidan, Perawat dan tenaga kesehatan selama masa covid-19 ini dalam pelayanan homecare dan pelayanan by phone dalam memfollow-up kesehatan ibu sebagai bentuk tugas bidan dalam memantau kesehatan ibu nifas dalam kegiatan KF 1- KF 4.

\section{Daftar Pustaka}

[1] Achadi EL. Kematian Maternal dan Neonatal di Indonesia. Rakerkernas 2019; pp.1-47, 2019.

[2] Woodd SL, Montoya A, Barreix M, Pi L, Calvert C, Rehman AM, et al. Incidence of maternal peripartum infection: $A$ systematic review and meta-analysis. PLoS Med;16(12), 2019.

[3] RI KK. Pedoman Bagi Ibu Hamil, Ibu Nifas, dan Bayi Baru Lahir selama Social Distancing; pp.9-12, 2020.

[4] Keppres No. 7 Tahun 2020. Keputusan Presiden RI No. 7 Tahun 2020 Tentang Gugus Tugas Percepatan Penanganan Corona Virus Disease 2019 (COVID-19) :1-8. 2020; 2019 (0107).
[5] POGI. Rekomendasi Penanganan Infeksi Virus Corona (Covid-19) Pada Maternal (Hamil, Bersalin Dan Nifas).

[6] Penanganan Infeksi Virus Corona Pada Matern;1(3):911, 2020. [Online].: https://pogi.or.id/publish/rek omendasi-penangananinfeksi-virus-corona-covid19-pada-maternal/

[7] Nurjanah S, Puspitaningrum D, Ismawati R. Hubungan karakteristik dengan perilaku ibu nifas dalam pencegahan infeksi luka perineum di RS. Roemani. Hub karakteristik dengan perilaku ibu nifas dalam Pencegah infeksi luka perineum di RS Roemani; (September): 336-47, 2017.

[8] Nurrahmaton N, Sartika D. Hubungan Pengetahuan Ibu Post Partum Tentang Perawatan Luka Perineum dengan Proses Penyembuhan Luka di Klinik Bersalin Hj. Nirmala Sapni, Am.keb Medan. J Bidan Komunitas. ;1(1):20, 2018.

[9] Notoatmodjo S. Promosi Kesehatan \& Ilmu Perilaku. Jakarta: Rineka Cipta, 2012.

[10] Jajoo D, Malu SK. Resarch Methodology. A Study Buy Decis Process Malls; 49-64, 2014. [Online].: http://shodhganga.inflibnet.a c.in/bitstream/10603/97412/5 /chapter 3.pdf.

[11] Kundre R. Personal Hygiene. ;5, 2017.

[12] WHO. $\quad W H O$ recommendations for prevention and treatment of maternal peripartum infections. World Heal Organ ;80, 2015. 
Jurnal Kebidanan Harapan Ibu Pekalongan

[13] Dudley L, Kettle C, Thomas PW, Ismail KMK. Perineal resuturing versus expectant management following vaginal delivery complicated by a dehisced wound (PREVIEW): A pilot and feasibility randomised controlled trial. BMJ Open. ;7(2), 2017.

[14] Puhaindran ME. Principles of wound healing. Diabet Foot Probl. ;9 (2). pp.395402, 2008.

[15] Schultz GS, Chin GA, Moldawer L, Diegelmann RF. Principles of wound healing. Mech Vasc Dis A Ref B Vasc Spec. 2011;:42350, (December) 2018.

[16] Rohmin A, Octariani B, Jania M. Faktor Risiko yang Mempengaruhi Lama Penyembuhan Luka Perineum pada Ibu Post Partum. ;449-54, 2015

[17] Farrag E, Eswi S, Badran ${ }^{3}$ haitham. Effect Of Postnatal Kegel Exercises on Episiotomy Pain and Wound Healing Among Primiparous Women. ;5(3):24-31, 2016. [Online].

www.iosrjournals.org

[18] Khusniyati E, Purwati H. Influence of Kegel Exercises on Duration of Healing Perineal To Women Postpartum. J Kesehat Ibu dan Anak.;12(2):31-7, 2018.

[19] Bagi P, Hamil IBU. Selama Social Distancing. ;11. 2020

[20] Wednesday P. Coronavirus ( COVID-19) Infection in Pregnancy.:1-62, May 2020.
[21] Alatas HS. Tanya Jawab seputar (Ibu Hamil, Ibu Bersalin dan Ibu Menyusui )* 19.

[22] Primadona P. The Process Of Healing Proliferation:;13 (September):1-5, 2015.

[23] Range MH. ar e Lt d ar e Pe Lt d, 2018.

[24] acKay D, Miller AL. Nutritional Support for Wound Healing. Altern Med Rev.;8(4):359-77, 2003.

[25] Mottola MF. CrossRef Listing of Deleted DOIs. CrossRef List Deleted DOIs. 2007, January 2003.

[26] Kilani HA, Shukri R. Postnatal Exercise Programme on the Health Related Fitness of Omani Primi Postnatal Women, May 2012.

[27] Happy M, Sari N, Kebidanan J, Kebidanan J, Semarang PK, Nifas M. Efektifitas Latihan Senam Yogaterhadap Proses Involusi Uterus Ibu Nifas Di Praktek Mandiri Bidan Wilayah.

[28] Uzaimi A, Febriand Abdel J, Armaidah R. No Acta Univ Agric Silvic Mendelianae Brun.;16(2):39-55, 2015.

[29] E. Montgomery-Downs H, Stremler R, P. Insana S. Postpartum Sleep in New Mothers and Fathers. Open Sleep J.;6(1):87-97, 2014.

[30] Creti L, Libman E, Rizzo D, Fichten CS, Bailes S, Tran D-L, et al. Sleep in the Postpartum: Characteristics of First-Time, Healthy Mothers. Sleep Disord.;2017:1-10, 2017. 